\title{
The role of intracavernosal vasoactive agents to overcome impotence due to spinal cord injury
}

\author{
C M Earle BSc, ${ }^{1}$ E J Keogh FRACP, ${ }^{1}$ J K Ker FRCS,${ }^{2}$ D J Cherry MBBS,${ }^{1}$ \\ A G S Tulloch FRACS, ${ }^{1}$ D J Lord FRANZCP ${ }^{1}$ \\ ${ }^{1}$ Reproductive Medicine Research Institute, Sir Charles Gairdner Hospital, Verdun Street \\ Nedlands, Western Australia; ${ }^{2}$ Royal Perth Rehabilitation Hospital, Shenton Park, \\ Western Australia.
}

Twenty-two spinal cord injured men (mean age 35.2 years) referred because of
impotence were treated with intracavernosal vasoactive agents. Papaverine
$2-20 \mathrm{mg}$, papaverine $40 \mathrm{mg}$ plus phentolamine $0.5 \mathrm{mg}$ or prostaglandin E1
$(1-20 \mathrm{ug})$ were used. Nineteen responded and were taught to self administer the
medication with varying degrees of assistance from their partners. Fourteen men
participated in a postal survey; $12(86 \%)$ continued to use the drugs every 1 to 4
weeks and reported satisfaction with the method. Partner responses were
positive in half of the group and when not so it influenced the patients to
abandon or reduce the frequency of treatment. Counselling was essential to allay
anxiety. Clinical management was not compromised and side effects were
minimal. Overall we found this treatment effective, safe and worthwhile.

Key words: impotence; spinal cord injuries; intracavernosal injections; prostaglandin $\mathrm{E}_{1}$; papaverine.

\section{Introduction}

Until recently the only treatment option available to impotent men with spinal cord lesions was the insertion of a penile prosthesis. ${ }^{1}$ For those patients who found surgery unacceptable we set out to test the proposition that intracavernosal injections ${ }^{2-5}$ and the self injection technique ${ }^{6}$ is a viable alternative. The use of this technique for spinal cord injured men has been previously reported. $^{7-11}$ We report our experience of the outcome, complication rate and patient acceptance of this treatment.

\section{Methods}

Between August 1984 and June 1990, 1361 impotent patients received more than 3258 intracorporeal injections with a variety of vasoactive agents. Of these patients, 22 were spinal cord injured referred for evaluation of their impotence. The patients were assessed clinically and biochemically as de-

Correspondence: Dr E J Keogh. scribed previously ${ }^{12}$ and then offered intracavernosal injections. This procedure had been approved by the University of Western Australia Human Rights Committee and all patients signed a consent form.

Patients were placed supine or in a sitting position on an examination couch or were treated in their wheelchairs during and for 30 minutes after the injection. Systemic blood pressure was recorded as a baseline in case of any change in blood pressure. The right side of the penis about $4 \mathrm{~cm}$ from the glans was cleaned with an alcohol swab. The needle $(13 \mathrm{~mm} \times 26$ gauge) was inserted up to the hub and the drug was injected over about 5 seconds.

It had been our usual practice when administering papaverine to give an initial injection of $20 \mathrm{mg}(30 \mathrm{mg} / \mathrm{ml})$. As we observed that spinal cord injured patients were very sensitive to the drug the starting dose was revised to range from $2 \mathrm{mg}$ to $5 \mathrm{mg}$. Depending on the result of the initial injection, the dosage was varied with the aim of producing an erection suitable for intercourse, lasting for at least half an hour. 
The maximum dose of papaverine administered was $80 \mathrm{mg}$. If the patient failed to respond to papaverine then a mixture of papaverine $40 \mathrm{mg}$ and phentolamine $0.5 \mathrm{mg}$ was used.

During the study reports of cavernosal fibrosis were published ${ }^{13,14}$ and the efficacy of prostaglandin $E_{1}$ was discovered. ${ }^{15,16} \mathrm{We}$ therefore included prostaglandin $E_{1}$. As little as $1-2 \mu \mathrm{g}$ was often adequate to produce a full erectile response. Of the 22 patients treated, 19 had full erections. These 19 patients were then invited to learn the self injection technique. All did so. The 3 remaining patients elected to have no further treatment.

Patients were instructed to draw up the drugs aseptically and to inject them into the lateral aspect of the penis. It was emphasized that the corpus spongiosum and the dorsal neurovascular bundle should be avoided. Upon withdrawal of the needle the patients were instructed to massage the penis for about 3 minutes to distribute the drug bilaterally throughout the penile shaft. During the second lesson the patients were required to demonstrate their competence at drawing up and self injection. Patients and their partners needed only 2 supervised lessons before they could be given the apparatus to use at home. They were supplied with a kit containing instructions, the drug, syringes, alcohol swabs, 19 gauge needles for drawing up and 26 gauge needles for injection. Patients were warned of the complications of the treatment and a 24 hour on call emergency medical service was made available. All 19 patients were invited to take part in the survey. Fourteen patients did so.

\section{Results}

The mean age of the 14 survey participants was 35.2 years (range $20-45$ ) and the mean age of onset of the spinal lesion was 27 years (range 15-42). The levels of the lesions causing paraplegia and tetraplegia are listed in Table I. Eight men had upper motor neurone bladder dysfunction, 4 had lower motor neurone dysfunction and 2 complained of frequency and urgency.

Twelve of the $14(86 \%)$ continue to use
Table 1 Spinal lesion

\begin{tabular}{|c|c|c|c|c|c|c|c|}
\hline \multicolumn{4}{|c|}{ Paraplegia } & \multicolumn{4}{|c|}{ Tetraplegia } \\
\hline \multirow{2}{*}{\multicolumn{2}{|c|}{ Complete }} & \multicolumn{2}{|c|}{ Incomplete } & \multicolumn{2}{|c|}{ Complete } & \multirow{2}{*}{\multicolumn{2}{|c|}{$\begin{array}{l}\text { Incomplete } \\
\text { level n }\end{array}$}} \\
\hline & & & $\mathrm{n}$ & level & $\mathrm{n}$ & & \\
\hline T5 & 1 & & & $\mathrm{C} 5$ & 1 & C6 & 1 \\
\hline T8 & 2 & & & $\mathrm{C} 7$ & 1 & & \\
\hline T11 & 2 & T10 & 1 & & & & \\
\hline T12 & 1 & $\mathrm{~T} 12$ & 1 & & & & \\
\hline L1 & 2 & & & & & & \\
\hline $\mathrm{S} 1$ & 1 & & & & & & \\
\hline
\end{tabular}

the self injection technique from once a week to every 1-4 weeks. Eight patients used papaverine, one a combination of papavarine and phentolamine, and 3 used prostaglandin $E_{1}$. The erections lasted for one to 4 hours. Eight patients felt that their spontaneous erections improved whilst using the self injection technique. Five patients had unreliable spontaneous erections; 3 of these patients could have intercourse occasionally without resorting to the medication. Pain had been experienced by 2 patients only, one using papaverine and the other injecting papavarine and phentolamine.

Problems experienced by these patients included lack of confidence, blood in the urethra, prolonged erections and bruising.

The patients were asked if they would prefer an alternative form of treatment. Their responses were as follows: 4 said no, 3 wondered what else was available, 2 wanted a non injectable drug, one wanted a better injection technique, or a topical ointment and one sought sexual counselling.

The partners' subjective responses to the treatment were: it was 'good' $(n=4)$, 'improved their relationship' $(n=2)$, it was 'okay' $(\mathrm{n}=2)$, 'successful' $(\mathrm{n}=1)$, 'apprehensive' $(\mathrm{n}=1)$, 'not willing' $(\mathrm{n}=1)$, 'glad it was not required every time' $(n=1)$. The 2 patients who had stopped using the technique did so because of 'my partner's disapproval'. Of these one patient has requested an implant and the other has not sought further treatment.

\section{Conclusions}

Intracavernosal injection of vasoactive agents has been a most important advance in 
the management of impotence. ${ }^{2-5,16}$ This applies particularly to those who have had spinal injuries. Indeed these men are exquisitely sensitive to the drugs, requiring as little as $5 \%$ of the usual dose.

Papaverine was used initially in this study but reports of cavernosal fibrosis in clinical and animal studies led us to restrict its use. ${ }^{13,14}$ Currently we use it for those travelling overseas as the customs restrictions are minimal compared to prostaglandin $\mathrm{E}_{1}$ and, unlike the latter, it is stable at room temperature. Not all patients experience a positive response to the drug and after the dose has been steadily increased to a maximum of $40 \mathrm{mg}$ we have added phentolamine. ${ }^{4}$ This synergistic combination appears to rectify the biochemical lesion at 2 sites by direct relaxation of smooth muscle and alpha $_{2}$ adrenergic receptor blockade.

Prostaglandin $\mathrm{E}_{1}{ }^{5,15.16}$ has the advantage of being an endogenous substance with a shorter half life which is less likely to induce prolonged erections. It must be refrigerated at $4^{\circ} \mathrm{C}$, it has a shelf life of about 3 months and is more expensive than papaverine. Nonetheless the erectile response is more reliable than papaverine.

Aside from the difficulties inherent in a pharmacological agent, other problems occur in such couples. Unrealistic expectations of this treatment by the men involved included the resumption of normal sexual gratification. Likewise, their wives may aspire to pre-accident sexual activity. Conversely, in relationships commenced after the injury the woman may be a reluctant participant in sexual intercourse. Psychological factors of this nature highlight the subjective quality of information derived from the questionnaire.

Despite the reservations expressed, the majority of patients $(86 \%)$ found the treatment acceptable. It helped restore self confidence and the sustained erections allowed adequate intercourse despite the physical disability. This led to a greater sense of well being, improved self confidence, and improvement in the relationship between patient and partner.

In conclusion, we have found this pharmacological approach to impotence in spinal injury patients remarkably effective, well accepted and quite safe.

\section{References}

1 Collins KP, Hackler RH (1988) Complications of penile prostheses in the spinal cord injury population. $J$ Urol 140: 984-985.

2 Brindley GS (1983) Cavernosal alpha-blockade: a new technique for investigating and treating erectile impotence. B J Psychiatry 143: 332-337.

3 Virag R, Frydman D, Legman M, Virag H (1984) Intracavernous injection of papaverine as a diagnostic and therapeutic method in erectile failure. Angiology 35: 79-87.

4 Zorginiotti AW, Lefleur RS (1985) Auto-injection of vasoactive drug combination for vasculogenic impotence. J Urol 133: 39-41.

5 Earle CM, Keogh EJ, Wisniewski ZS et al (1990) Prostaglandin $E_{1}$ therapy for impotence, comparison with papaverine. J Urol 143: 57-59.

6 Watters GR, Keogh EJ, Earle CM (1988) Experience in the management of erectile dysfunction using the intracavernosal self-injection of vasoactive drugs. J Urol 140: 1417-1419.

7 Momose H, Natsume O, Yamamoto M, Suemori T, Yamada K (1987) Intracavernous injection of papaverine hydrochloride for impotence in patients with spinal cord injury. Hinyokika Kiyo 33(7): 1065-1069.

8 Wyndaele JJ, de Meyer JM, de Sy WA, Claessens H (1986) Intracavernous injection of vasoactive drugs, an alternative for treating impotence in spinal cord injury patients. Paraplegia 24(5): 271-275.

9 Bodner DR, Lindan R, Leffler E, Resmick MI (1987) The application of intracavernous injection of vasoactive medication for erection in men with spinal cord injury. J Urol 138: 310-311.

10 Sidi AA, Cameron JS, Dykstra DD, Reinberg Y, Lange PH (1987) Vasoactive intracavernous pharmacotherapy for the treatment of erectile impotence in men with spinal cord injury. $J$ Urol 138: 539-542.

11 Lloyd LK, Richards JS (1989) Intracavernous pharmacotherapy for management of erectile dysfunction in spinal cord injury. Paraplegia 27: 457-464.

12 Keogh EJ, Tulloch AGS, Csillag ER et al (1988) The diagnosis and management of impotence. Med J Aust 148: 494-498.

$13 \mathrm{Hu}$ KN, Burks C, Christy WC (1987) Fibrosis of tunica albuginea: complication of long-term intracavernous pharmacological self-injection. J Urol 138: $404-405$.

14 Juenemann KP, Benedict Yen TS, Lue TF, Tanagho EA (1988) The effect of chronic papaverine treatment 
on simiean erectile tissue. In: Proceedings of the Third Biennial World Meeting on Impotence, Boston, Massachusetts, abstract 80.

15 Adaikan PG, Tai Ny, Lau LC, Karim SM, Kottegoda SR (1984) A comparison of some pharmacological actions of prostaglandin $\mathrm{E}_{1}, 6$-oxo-PGE $\mathrm{P}_{1}$ and PG12. Prostaglandins 27: 505-516.

16 Virag R, Adaikan PG (1987) Effects of prostaglandin $E_{1}$ on penile erection and erectile failure. Letter to the Editor. J Urol 140: 1417-1419. 